\title{
Game Method in Preschool English Teaching
}

\author{
Wan-Chuan Yu \\ CLAL, Guangdong University of Foreign Studies, Guangzhou Guangdong 510420, China \\ IFLCR, Lingnan Normal University, Zhanjiang Guangdong 5240148, China
}

Received: December 21, 2015 Accepted: January 6, 2016 Published: January 11, 2016

doi:10.5296/ijele.v4i1.8845 URL: http://dx.doi.org/10.5296/ijele.v4i1.8:845

\begin{abstract}
Interest is a great motivation for the study of almost everything, particularly for L2 study. To preschool students, games are quite attractive. Therefore game method is a good way to help students to learn English, especially in kindergartens. It fits the characteristics of preschool students, providing learning motivation, lowering students' stress and offering the opportunity for real communication. Nowadays, more and more teachers are using games effectively in class to improve their teaching. In order to apply game method effectively in teaching English in kindergartens, games must be designed purposeful, interesting, various, heuristic and student-oriented. During the course of games (pre-games, in games and post-games), some details should be paid more attention to.
\end{abstract}

Keywords: game method, motivation, English Teaching, preschool student 


\section{Introduction}

In 1978, the $75^{\text {th }}$ Nobel Laureates conference was held in Paris. Pyotr Leonidovich Kapitsa, the leading Soviet physicist and Nobel Prize winner in Physics laureate, got such a question "Which period in your whole life means most?" "In the nursery", Kapitsa answered peacefully. An enthusiastic applause lasted quite long for this reply. It reflects that preschool education may give people far-reaching implications and impact through their life. And nowadays, more and more attention are being paid to preschool education.

With the booming tide of English learning globally, early L2 ELT attracts more concerns from parents, nursery schools and researchers. Since 1990's, early English training classes and materials have flocked into the public education area. Most Chinese kindergartens have opened English classes to meet the need. Now early English learning in cities has been very popular and so many bilingual kindergartens named "Chinese-English Bilingual Kindergarten" and "Foreign Language Art Kindergarten" have sprung up like mushrooms after rain.

Up to now, it is absolutely not a question whether or not to teach English in kindergartens, but what to teach and how to teach it well. Most scholars, educators and teachers agree on that the objective of kindergarten English teaching is to cultivate interest in the language, develop basic communication skills and crude understanding of foreign culture.

Charles Darwin once recalled: "Looking back as well as I can at my character during my school life, the only qualities which at this period promised well for the future, were, that I had strong and diversified tastes, much zeal for whatever interested me, and a keen pleasure in understanding any complex subject or thing." (Charles Darwin, 1887:6) It's believed that most learning demands interest. To some extent, language learning needsi more interest than other subjects. How to evoke the learners' interest and keep their passion in learning is a teacher's initial task and challenge. Game method is an efficient way to achieve this goal in English teaching. The article will mainly illustrate the reasons why we should use games, what rules we should obey, and how to design good games in preschool English teaching.

\section{Games and Teaching}

\subsection{Definition of Games}

There are a variety of definitions for games. Jill Hadfield (1984) defined games as activities in which players engage in artificial conflict, are defined by rules, and have a goal and an element of fun, which results in a quantifiable outcome. Similarly, Spodek Bernard \& Saracho Olivia (1994:271) deemed that "games are a different kind of play activities. They are highly structured and include specific rules to be followed." Brown (1996:176) argued "a game could be any activity that firms a technique into each unit that can be scored in some way." Johann Huizinga (1998) defined games as free activities standing quite consciously outside "ordinary" life as being "not serious", but at the same time absorbing the player intensely and utterly.

In view of the above, we can learn that a "game" means an activity which is done for amusement, often with challenge, and an activity in which the learners play and usually 
interact with others.

\subsection{Game Method in Teaching}

According to the explanation of Longman Dictionary of Language Teaching \& Applied Linguistics, a "game" in language teaching can be defined as an organized activity that usually has the following properties:

a. a particular task or objective;

b. a set of rules;

c. competition between players;

d. communication between players by spoken or written language.

(Richards Jack C, Platt John, Platt Heidi, 1992:191)

Games are activities governed by rules, in which the player will enjoy and have fun. They are not only a diversion, a break from routine activities, but a measure in which learner uses the language in the game (Byrne, 1995).

Lu Ziwen (2005) points out that English teaching games are playing activities with dramatic conflicts, with the purpose of utilizing English knowledge and helping to acquire communicative competence. He emphasizes four indispensable characteristics of English teaching games:

a. Dramatic. The characteristics of "drama" are differing from the ordinary activities;

b. Playable. Participation, presentation, multi-sensory, and multiple intelligence activities are compliant to the players' interests and mental features, and with clear rules;

c. Educational. Games are played for language learning.

With those points, we can look game teaching upon as: an efficient teaching method in which by utilizing a set of playing activities, players get involved in certain tasks to accomplish teaching purposes. In some Chinese kindergartens, game teaching has grown into popular teaching techniques most frequently used. The teachers employ various game activities in teaching to help the children to develop their English competence as well as consolidate their learning.

\subsection{Current Researches in China}

In China, extremely great importance has been attached to education since ancient times. Many educators noticed the role of games in early childhood education long ago. For instance, early in Song and Ming dynasty, teachers not only taught children the daily routines and moral rites, but also managed to foster children's interest in learning. They stressed the necessity to make learning enjoyable. Cheng Yi (A prestigious educator in Song dynasty) noted that if your teaching was boring, nobody could learn well. Wang Shouren (an educator in Ming dynasty) claimed that early teaching should make children happy and enjoyed. Thus, a variety of game elements like singing, dancing, and story-telling were added to the teaching 
process, in order to make children learn knowledge with a light heart (Wu Yexuan, 1996:33).

A number of recent researches also show their preference and passion in game teaching. $\mathrm{Li}$ Shaoqun (2011) demonstrates that the advantage of games is not only helping teachers to finish the teaching objectives successfully, but attracting students to take a more active part in learning English. Xie Guihua (2006) proves that games can spur cooperation between students and help them to learn from each other and make progress together during the teaching process. Hao Hong (2011) demonstrates, "During classroom games, students focus on the activity and end up with a subconscious absorption of language knowledge."

The educational value of game method has been appreciated ever and again. It is now widely believed that games are commendable teaching aids in English teaching, especially in preschool. Therefore, it is of great significance to revisit and explore the practical use in more detail in order to draw on it more effectively.

\section{The Value of Game Teaching}

\subsection{Theoretical Foundation}

\subsubsection{The Multiple Intelligences Theory}

The theory of multiple intelligences was proposed by Howard Gardner in 1983 to analyze and better describe the concept of intelligence. Gardner expounds that the concept of intelligence as traditionally defined in psychometrics (IQ tests) does not sufficiently describe the wide variety of human cognitive abilities. In fact, generally individuals have eight basic intelligences: Verbal-linguistic intelligence, Musical-rhythmic intelligence, Logical-mathematical intelligence, Visual-spatial intelligence, Bodily-kinesthetic intelligence, Intrapersonal intelligence, Interpersonal intelligence and Naturalist intelligence.

The theory of Multiple Intelligences concentrates on the diversity, difference and uniqueness of intelligence which validates teachers' everyday experience: students think and learn in many different ways. It also provides teachers with conceptual framework for organizing and reflecting on curriculum assessment and pedagogical practices. In turn, this reflection has led many teachers to adopt game method that might better meet the needs of various learners in their class.

\subsubsection{The Constructivism Learning Theory (CLT)}

CLT refers to the concept that humans generate knowledge and meaning from an interaction between their experiences and their ideas. Formalization of the theory of constructivism is generally attributed to Jean Piaget, who articulated mechanisms by which knowledge is internalized by learners. He suggested that through the processes of accommodation and assimilation, individuals construct new knowledge from their experiences. The core of learning process is not the teacher but students. The teacher only plays a role as an organizer, a director, a helper and a promoter. This methodology focuses on making the students actively construct their knowledge learning themselves (Tobias, S.; Duffy, T. M. 2009). It requires the teachers change their roles to be the guiders, helpers or promoters instead of the knowledge fillers and suppliers. The students should be the constructors of knowledge rather 
than passive receivers.

\subsubsection{Psychology Theory}

Early language learning is likely to result in long-term outcome if learning is maintained and reinforced later. Penfield \& Robert's (1959) study on lateralization demonstrated that it is better to start to learn a foreign language before puberty. However, results of other experiments indicate otherwise. Lateralization occurs before four years old, and that does not interfere with the language acquisition (Krashen, 1973). Lateralization can take place at different ages for different people, and the critical period is not a certain age (Scovel, 1981). However, research suggests that children do have advantages in speech perception and mentality. Generally speaking, preschoolers have some psychological advantages which can facilitate the learning of a foreign language. Based on preschoolers' psychology, some teachers have tried to transform language learning to interesting games so as to offer the students with sufficient communication circumstance.

For the sake of age, most preschoolers' ability to control and regulate their mind and behaviors is still weak and they are susceptible to most distractions so that they can't concentrate for a long time. According to Cooper, Moodley \& Reynell (1978), children's attention develops as they grow older. In the third year, single-channel attention develops and attention must be fully obtained to shift to a different task. In the fourth year, children can control their own focus of attention to some extent. In the fifth year, they can perform another activity while listening to the teacher who is giving directions. By the sixth year, they have developed flexible and sustained attention. To help kids sustain their attention, a teacher should manage to prevent them from being distracted by irrelevant things and focus on one task.

\subsection{Advantages of Game Teaching}

\subsubsection{Beseem the Preschool Students}

Most of the students in kindergarten are at the age of 3 to 6 , who love fun and playing games. Mark Pennington (2008) states that most students share the following characteristics: (1) Curious and willing to learn things they consider useful; (2) Enjoy solving "real-life" problems; (3) Need to feel part of a peer group, consisting of boys and girls, and are influenced by peer pressure and conformity to their group; (4) Prefer active over passive learning activities that involve working with their peers; (5) Need adult support, guidance, and calm direction. In kindergarten, the 3-year-olds can sustain their attention for 3-5 minutes, the 4-year-olds about 10 minutes, and the 5-year-oles 10-15 minutes. The praise and support from the teacher can serve as an important source for self-regulation in the kindergarten. With teachers' encouragement and discipline, children are more likely to develop positive self-esteem, becoming more responsible, and will follow through assigned activities. English teaching which stresses grammar learning and memorizing may make the kids lose their interest and motivation. Games fit the psychological features of preschool students, for they can easily grasp the students' attention and improve their interest in learning English. When playing a competitive game, students are trying their best to win or stand out on the behalf of 
their team. They may behave very actively while playing because they want to have the chance to show, to score and to win. By means of games teacher can accomplish the purpose of learning in playing, and playing in learning.

\subsubsection{Provide Learning Motivation}

One of the main reasons why games are considered necessary learning aids is that learners are motivated to learn the language when they are in a game. McCallum (1980:9) emphasizes that "games automatically stimulate student interest, and a properly introduced game can be one of the highest motivating techniques." "Games spur motivation and students get very absorbed in the competitive aspects of games; moreover, they try harder at games than in other courses" (Avedon, 1971). In other words, games stimulate students' interest in classroom activities and as a result, students become motivated and are willing to learn.

To participate in a game, the students need to master the new ideas, words, grammar, knowledge, and so on, which the teacher have presented to them before. It can be clearly seen that games can capture students' attention and participation. They can provide a learning motivation to students which urges them to learn more. Even in a very easy game like dictation, students also must be very concentrated in order to win.

\subsubsection{Lower Students' Stress}

Another advantage is that students' anxiety in language learning decreases as games are employed. In conventional language class, learners often feel stressful because they have to be confronted with the unfamiliar target language. Besides, learners may become too anxious about being criticized and punished by their teachers when they make a mistake. Schultz (1988) argues that stress is a major hindrance in language learning process. This process [Learning language in traditional way] is by its nature time consuming and stress provoking. It raises the stress level to a point at which it interferes with student attention and efficiency and undermines motivation. One method has been developed to make students forget that they are in class, relaxing students by engaging them in stress-reducing task (games).

Games are advantageous at this point because they reduce anxiety, increase positive feelings and improve self-confidence because learners will not be afraid of likely punishment or criticism while practicing the target language freely in games (Crookal, 1990:112).

\subsubsection{Offer the Opportunity for Real Communication}

To develop an efficient and effective learning system, teachers need to provide an open, and flexible learning environment for learners, for learning environment plays an important role in English class. Games bring in real-life situations to the classroom, providing learners with more opportunities to use the target language. In playing games, various contexts can be created to enable unconscious learning because learners' attention is on the message conveyed, not on the linguistic forms. Therefore, when students focus on a game, they can acquire language to some extent in the same way they acquire their mother tongue. Celce-Murcia (1979:54) notes that "in games, language use takes precedence over language practice, and in this sense games help bring the classroom to the real world, no matter how 
contrived they may be." Playing games in the classroom can enormously increase students' ability in using language because students have more chances to use language in the situations provided.

\section{Effective Game Teaching}

\subsection{The Principle of Designing Games}

There are a great number of games for teachers to choose in language class (see Andrew Wright, 2006). However, in deciding which game to use in a particular class and which game will be the most appropriate and most efficient with their students, teachers must take many factors into account.

\subsubsection{Purposeful}

First of all, games must be designed with specific purposes. They should not be regarded as marginal activities, filling in odd moments when teachers and class have nothing better to do. Because classroom games are devices for teaching, they must be closely related with the language knowledge. If a game designed only to make students happy, it is only an ordiary game not fit for language teaching. A classroom game must be appropriate and carefully planned. Brumfit, Christopher, Moon, Jayne and Ray Tongue (1995:33) demonstrate that "we should consider whether the game-like activity is for children only to make the lesson more attractive and protect them from being bored or whether we tend to revise and practice some particular part of grammar, vocabulary, etc. It is important not to waste our time. Some activities have too complicated rules or on the other hand, some activities are too simple, and both the cases make children speak their native language, which we definitely want to avoid."

So, when designing a classroom game, we should consider sufficiently about the key and difficult points of language leaning to cover, and what knowledge or ability we want students to acquire through the game. In general, the following aspects are always included in the outlines of designing the classroom games for teaching English in kindergarten (Jiang, 2010):

a. Make the students review the words they have learnt and enlarge their vocabulary.

b. Improve their interest in learning English and help them enjoy learning.

c. Develop the students' ability of listening, speaking and communicating.

d. Enhance the cooperative spirit.

\subsubsection{Interesting}

One of the functions of games is to improve students' interest in learning English. If the games are boring or dull, how can they implement this function? In addition, being interesting is one of the most prominent elements that should be taken into account first. When we designing a game, we should make sure that the game is attractive enough to grasp students' attention and make them eager to take a part.

However, it should be kept in mind that the main function of games is teaching language, but not just making fun. It is not advisable to play games only for games' sake, that is, while 
enjoying playing, students miss the orientation totally to practice the target language as required. What's more, if students get too excited, it's hard for teachers to control the class. The degree of enjoyment should be evaluated and observed accordingly.

\subsubsection{Various}

Although most games are interesting, it doesn't imply that teachers can fix on one or several games. If the teachers don't alter the forms of games flexibly, students are liable to get tired, and games will become boring and lose its amazing function. For example, a teacher may choose the guessing game to teach vocabulary in unit 1 , unit 2 , and unit 3 . When it comes to unit 4 , before the vocabulary class, the students might already figure out what they are going to do and lose the interest in it. But if the teacher uses Bingo in unit 1, Riddle in unit 2 and Competition in unit 3, then in unit 4, the students will be expecting something novel and eager to get well prepared for it. So teachers can change different forms of games alternately when designing the class. Various and creative Games can help to keep students' enthusiasm in learning English.

\subsubsection{Heuristic}

It is a common sense now that in L2 class teaching language knowledge is far from enough, and developing students' competence for communication has become the main objective. It requests that the teaching activities should be closely related to real life, inspiring imagination and enlightening to innovation. So the game designed for the use in the classroom should be heuristic. When playing games, teachers are supposed to give some tips or directions to lead students to think in English and use English, instead of just presenting them the new words and structures and ask them to practice.

\subsubsection{Student-centered}

In the traditional class, teachers used to play a role as a leader and dominator ( $\mathrm{Yu} \& \mathrm{Niu}$, 2010). And what students need to do is listening to them and taking notes, trying to memorize what is taught and recall it in examination. However, Constructivism theory deems that teaching should be centered on students rather than on teachers so as to achieve the main objectives of teaching. Teachers are expected to give more time to the students to learn through more communication practice in class. One of the functions of game method is to develop students' oral competence and the games are student-focused activities. In playing games, learners are encouraged to take more active role in their learning process. As a result, they can have a chance to develop their competence rather than just learn language knowledge.

\subsection{The Procedure of Game Teaching}

It is necessary for those who want to use games as a learning aid to be concerned about how to use them effectively. What should they do in pre-games, while-games and post-games?

\subsubsection{Pre-games}

First of all, determine the purpose. We know that games are not just for fun. The teacher 
should keep in mind what students would learn through these games. So before using a game in class, teachers should confirm the purpose of this game. If they want to use a game to teach vocabulary, they should ensure which words students are required to master during the game first. But what they should pay more attention to is the knowledge they choose to teach in the game should fit the level of the students'. Here is an episode excerpts from Classroom Activity 5 Nov, 15, 2006.

Episode 1:

Number game is a game to consolidate the numbers. According to the teaching material and teaching plan, the simple numbers are arranged to be taught in Unit 6 PEP1 for Grade 3.

T: Now let's count the numbers from one to ten then ten to one.

One, two, three, four, five, six, seven, eight, nine, ten, ten, nine, eight, seven, six, five, four, three, two, one. Hands up

Ss :(many of the students put their hands up but some students do their others things.)

Ss: One, two, three, four, five, six, seven, eight, nine, ten, ten, nine, eight, seven, six, five, four, three, two, one.

S1: One, two, three, four, five, six, seven, eight, nine, ten, ten, nine, eight, seven, six, five, four, three, two, one. (Others laugh with hahaha)

T: Very good, a game for you!

Miss He says one (showing one finger), you should 一个人站。Miss He says two (showing two fingers), 两个人站在一起, 没有找到朋友的回到自己的座位上, back to your seats. Miss He says four (showing four fingers), 4 个人站在一起, 没有找到朋友的回到自己的位 子上, back to your seats.

Understand? Who is the winner? Come on, leave your seat, 离开位置。

Ss: $O K !$

(While 6 boy students sit all the same.)

$T:($ Say to the 6 students) Come on, let's play.

S1: 老师, 我不想玩, 太幼稚啦, 太简单啦, 不想玩。

$S 2$ : 就是啊, 我们大了, 才不玩这种游戏呢。

T: Never mind, now listen, one.

Ss: Stand lonely.

T: Two

Ss: Stand in pairs. (a boy stands with a boy and a girl stands with a girl in pairs and the last boy has to stand with the girl but they stand far apart.) 
T: Three

Ss: Stand with other two children (standing with the same gender as before. At last two boys and two girls have not found their friends. They do not want to leave their friends with the different sex. At last, two boys go to their seats directly with the words “我们回去好啦, 不 玩了, 我才不跟女孩子一组呢”。Two girls have to go back to the seats too.

Since the game is too easy, some students lose interesting in playing the game. In the same way, if the game beyond the current linguistic level too much, it also decreases students' interesting.

Second, choose the pattern. Because games are various, teachers should choose one pattern of them which is the most suitable for the purpose of this game. Such as they can choose guessing game, bingo, charades to teach vocabulary, use role-play, make dialogues, survey to teach grammar, or tongue twister, songs, gossip to teach oral English and so on.

Then, make out the rules step by step. Before explaining the rules to the class, the teachers should first understand clearly how the game is played. It concludes when to use this game, whether the students will be divided into pairs or groups, what the students are asked to do, what they cannot do, and so on.

The last one, make the preparation. Since it is rather difficult to find a game that meets all the needs of the purposes, careful preparation of teachers is necessary. Teachers may need some extra equipment or materials to play the game, but most of the time these equipment and materials are not available in the. So they should make a good preparation before playing the game.

\subsubsection{While-games}

When it is time to play the game, teachers should explain its rules to students first and in a direct and non-complicated way. If the students cannot understand how to play the game, there is no educational purpose in playing the game. So it may be necessary to use the mother tongue to explain the rules, as they are just preschool students who merely touch English for a short time. In addition, demonstrations may also be necessary, because they can help the students to understand the rules clearly and easily.

Episode 2

T: Now let's play a funny game, 我们来玩一个有趣的游戏。

Ss: Great!

T: Do as T Say, 找我说的做. 当我说 Act like A, 你们就 2 个人或者三个人合作, 用身体 部位摆出相应的字母 $A$ 。如果我说 Act like B, 你们该怎么做呀?

Ss: 两人合作摆出一个B。

T: Great! Now let's begin。Act like A.

Ss pose A 
T: Act like Z.

Ss pose Z...

(Classroom Activity 8 Oct 31, 2005)

Then, in playing the game, teachers should play a role as a director (look at episode 2) or a participator instead of a leader. As a director, the teachers should control the whole class during the game, direct the students to play the game successfully and then achieve the purpose of the game. And in the make dialogues, discuss, survey and make reports, or role-play games, the teachers can play a role as a participator, they should join in the game with the students. It can help the teachers to know more about the students, give some tips to them and help the students to finish the game. It can also lower the students' stress if the teachers can join them.

Furthermore, teachers are not recommended to interrupt to correct the mistakes of students during the game. According to Celce-Murcia (1979:54), "interruptions should be as infrequent as possible so as not to detract from the student's interest in the game. An alternative to immediate correction is to make note of errors and discuss them when the game is over". Thus, if the students make mistakes in game, the teachers should remember in mind and correct the common mistakes in the class or ask the students to try to correct them by themselves after the game, but not correct them immediately.

Besides, during the game, teachers should pay more attention to the students who are shy and often be quiet in the class. Playing games is a good way to improve the students' interest in learning English and lower their stress. In this situation, the shy students will also be eager to show themselves. So the teachers should give them more encouragement and chances, help them to be more confident in learning English.

\subsubsection{Post-games}

After playing the game, the teachers should make an evaluation and conclusion to students. They should praise the students who have done better in the game and encourage those who are not active enough. The teachers can also give the winner some prize - a little paper of flower which may not be of any significance to adults but for the little kids it may mean a great honor and pride, they are very fond of it and glad to tell their parents they have done a good job in the kindergarten.

In addition to all of these, the last thing teachers should do is to make a reflection of this game. It contains the questions of whether the purpose of the game is achieved or not, whether there any problems in playing the game, how to improve it next time, and so on.

In general, these are the procedures and some details should be paid attention to when using games effectively in the kindergarten.

\section{Conclusion}

Game method is of great value and can be used to develop kids' language competence, because it fits in with the characteristic of kindergarten students, provides learning motivation, lowers their stress, promotes their communication in cooperation, and gives them the 
opportunity for genuine communication. Far more than just being played for fun, it has great educational values in language teaching and learning. Since game method is such a precious aid in teaching English, teachers should pay more attention to it and try to use it effectively, instead of using it just in order to make students feel funny or as a marginal activity filling in odd moments when teachers and class have nothing better to do.

\section{References}

Avedon, M. E., \& B. S. (1971). Brian Learning through Games. The Study of Games, New York: John Wiley \& Sons. pp. 315-321.

Brumfit, Christopher, Moon, Jayne, \& Ray Tongue. (1995). Teaching English to Children: From Practice to Principle. London: Longman Group UK Limited. p. 33.

Brown H Douglas. (2001). Understanding Research in Second Language learning. Beijing: Foreign Language Teaching and Research Press.

Byrne, D. (1995). Games. Teaching Oral English. Harlow: Longman Group UK Limited.

Celce-Murcia, M., \& L. McIntosh. (Eds.) (1979). Teaching English as a Second or Foreign Language. Newyork: Newbury House.

Charles Darwin. The Autobiography of Charles Darwin [EB/OL]. Retrieved from http://ishare.iask.sina.com.cn/f/33464987.html

Cooper, J., Moodley, M., \& Reynell, J. (1978). Helping Language Development. London: Edward Arnold.

Guihua Xie. (2006). An Analysis to the Characteristics and Principles of Classroom Games in Foreign Languages Teachin. Journal of Guizhou University for Ethnic Minorities (Philosophy and social science), 99(5), 190-193.

Hadfield, Jill. (1990). An Collection of Games and Activities for Low to Mid-Intermediate students of English. Intermediate Communication Games. Hong Kong: Thomus and Nelson and Nelson and Sons Limited.

Hao Hong. (2011). Teaching English Grammar with Fun. Private Science and Technology, (3), 81.

Jianfen Jiang. (2010). The Application of Games in Efficient TES Classroom. Navigations in Arts \& Sciences, (5), 15-16.

Johann Huizinga. (1998). Human beings: Players. Guiyang: Guizhou People Press.

Krashen, S. (1973). Lateralization, language learning, and the Critical Period: some new evidence. Language learning, (23), 63-74.

McCallum, G. P. (1980). 101 word games: For students of English as a second or foreign language. Oxford: Oxford University Press.

Pennington, Mark. Characteristics of Middle School Learners [J/OL]. Retrieved from 


\section{Macrothink \\ International Journal of English Language Education \\ ISSN 2325-0887 \\ 2016, Vol. 4, No. 1}

http://EzineArticles.com/?expert=Mark_Pennington

Richards Jack C, Platt John, Platt Heidi. (1992). Longman Dictionary of Language Teaching \& Applied Linguistics. Beijing: Foreign Language Teaching and Research Press. p. 191.

Schultz, M., \& A. (1988). Fisher. Interacting in the Language Classroom: Games for All Reasons. Massachusetts: Addison-Wesley Publishing Company.

Scovel, T. (1988). A time to Speak: A Psychological Inquiry into the Critical Period for Human speech. Rowley, Mass: Newbury House.

Shaoqun Li. (2011). A Glimpse of Games in ELT. Digest of Science \& Education, (2), 139-140.

Spodek Bernard, \& Sarscho Olivia N. (1994). Right from the Start: Teaching Children Ages Three to Eight. Allyn and Baco.

Tobias, S., \& Duffy, T. M. (2009). Constructivist instruction: Success or failure? New York: Taylor \& Francis.

Wu Yexuan. (1996). English Language Teaching in China: Trends and Challenges. TESOL Quaterly, pp. 35, 191-194.

Yue Yu, \& Yuehui Niu. (2010). The Use and Significance of Games and Activities in FLT. Journal of language Study (FLT), (5), 138-141.

Ziwen Lu. (2005). Teaching Theories \& Cases of Games Teaching in Primary School. Beijing: China Electric Power Press.

\section{Copyright Disclaimer}

Copyright for this article is retained by the author(s), with first publication rights granted to the journal.

This is an open-access article distributed under the terms and conditions of the Creative Commons Attribution license (http://creativecommons.org/licenses/by/3.0/). 